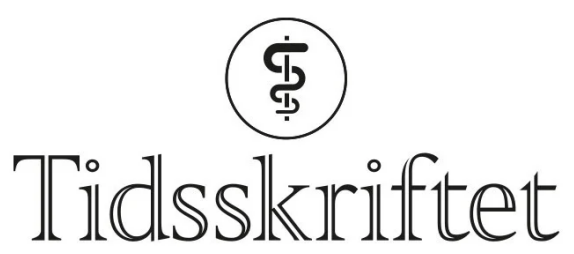

DEN NORSKE LEGEFORENING

\title{
Covid-19: Barn er ikke små voksne
}

\section{LEDER}

\section{KETIL STØRDAL}

\section{ketil.stordal@medisin.uio.no}

Ketil Størdal er spesialist i barnesykdommer, overlege ved Oslo universitetssykehus og professor ved Institutt for klinisk medisin, Universitetet i Oslo. Han har tidligere vært ansatt ved Folkehelseinstituttet og deltar i epidemiologiske studier og vurdering av covid-19-vaksinering av barn og ungdom.

Forfatteren har fylt ut ICMJE-skjemaet og oppgir ingen interessekonflikter.

\section{Covid-19 gir grunn til å friske opp et mantra fra undervisningen i barnesykdommer: Barn er ikke små voksne. Immunresponsen er avhengig av alder og viser seg i form av andre sykdomsbilder og i responsen på vaksiner.}

I midten av april 2020 ble åtte barn innlagt på sykehus i det sørlige London med et nytt sykdomsbilde etter infeksjon med SARS-CoV-2. Tre uker senere publiserte The Lancet kasusserien, som på det tidspunktet beskrev over 20 innlagte barn (1). I l lpet av uker rapporterte klinikere fra Frankrike, Italia og USA om barn med samme alvorlige sykdomsbilde. Effektiv digital kunnskapsdeling under pandemien gjorde leger forberedt på å oppdage og behandle sykdommen i tide. Multiorgan inflammatorisk syndrom assosiert med covid-19 (MIS-C) ble den nye barnesykdommen. I oversiktsartikkelen som nå publiseres i Tidsskriftet, beskriver Yi Hu og medarbeidere sykdomsbildet, forekomst og

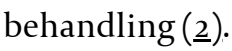

Sykdomsbildet kan minne om andre kjente hyperinflammatoriske tilstander som Kawasakis syndrom. En svensk-italiensk forskergruppe kunne imidlertid raskt vise at immunologiske kjennetegn skilte multiorgan inflammatorisk syndrom assosiert med covid-19 tydelig fra Kawasakis syndrom (3). Selv om MIS-C-pasientene er eldre enn barn med Kawasakis syndrom, viser sykdommene hvordan disse immunologiske reaksjonene langt på vei er unike for barn. I Verdens helseorganisasjons terminologi står C i forkortelsen MIS$\mathrm{C}$ for children. Et lignende sykdomsbilde er også blitt beskrevet hos voksne og er gitt betegnelsen MIS-A, der A-en står for adult (4). Denne komplikasjonen etter primær covid19 er meget sjelden og så langt omtalt i enkeltkasuistikker eller som kasusserier. For både barn og voksne mangler eksakte data for risiko, fordi sann insidens av primærinfeksjonen ikke er kjent. 
En stor andel barn forblir symptomfrie gjennom en primærinfeksjon, og akutt covid-19sykdom hos barn har et langt mildere forløp enn hos voksne og eldre. Folkehelseinstituttet har anslått at $60 \%$ av smitte blir oppdaget. Dersom dette er riktig for unge under 18 år, har omkring 2 av 1 ooo smittede under 18 år i Norge hatt behov for sykehusinnleggelse på grunn av covid-19-sykdom, ifølge en artikkel som ennå ikke er fagfellevurdert (5). Multiorgan inflammatorisk syndrom hos barn utgjør omkring $1 / 4$ av disse innleggelsene.

Hva vet vi om langvarige symptomer etter akutt infeksjon med SARS-CoV-2? En sveitsisk studie viste noe $\varnothing \mathrm{kt}$ forekomst av symptomer etter 3-6 måneder, men ingen forskjell i selvvurdert helse mellom 6-16-åringer med og uten gjennomgått covid-19 (므). I en britisk studie i samme aldersgruppe rapporterte 1,8 \% symptomer etter åtte uker, og det var kortere varighet av symptomer hos barn under 12 år enn 12-17-åringer (7.). I en fersk systematisk oversiktsartikkel påpekes mangelen på gode langtidsstudier på barn og ungdom (ㅁ). Her vil viktige kvalitetsmål være at utvalget av pasienter er representativt og at frafallet er lavt, slik at man unngår skjevheter der grad av symptomtrykk kan påvirke responsraten. Kontrollgrupper bør inkludere en testnegativ gruppe med andre virale luftveisinfeksjoner. Viktigst i denne sammenhengen er imidlertid at funn fra studier på voksne ikke ekstrapoleres til barn og ungdom.

\section{"Viktigst $i$ denne sammenhengen er at funn fra studier på voksne ikke ekstrapoleres til barn og ungdom»}

Vi mangler fortsatt godkjente vaksiner til barn under 12 år. Antistoffresponsen på BioNtech/Pfizers mRNA-vaksine er kraftigere hos 12-15-åringer enn hos unge voksne, og beskyttelsen mot infeksjon minst like god (9.). Kardiale bivirkninger som perikarditt og myokarditt er sjeldne, men hyppigst etter andre dose hos gutter og i de yngste aldersgruppene (10). Derfor er ikke avveiningen om individuell nytte for å beskytte mot primærinfeksjon sett mot mulige bivirkninger av vaksine i denne aldersgruppa like åpenbart i favør av allmenn vaksinering som hos voksne. Anbefalingen fra Folkehelseinstituttet er foreløpig å tilby 12-15-åringer én dose og å vurdere risiko og nytte før eventuelt dose nr. 2 blir anbefalt. Effekt målt som beskyttelse mot smittespredning basert på studier uten barn og ungdom er ikke uten videre overførbare til disse aldersgruppene.

Medisinske sannheter skal ikke reservasjonsløst strekkes utover populasjonen en observasjon kommer fra. Fra et pediatrisk synspunkt er det grunn til å minne om dette både i diskusjonen om vaksiner og om kort og lang covid.

\section{LITTERATUR}

1. Riphagen S, Gomez X, Gonzalez-Martinez C et al. Hyperinflammatory shock in children during COVID-19 pandemic. Lancet 2020; 395: 1607-8. [PubMed][CrossRef]

2. Hu Y, Rojahn AE, Flatø B. Multiorgan inflammatorisk syndrom hos barn og ungdom etter covid-19infeksjon. Tidsskr Nor Legeforen 2021; 141. doi: 10.4045/tidsskr.20.1040. [CrossRef]

3. Consiglio CR, Cotugno N, Sardh F et al. The Immunology of Multisystem Inflammatory Syndrome in Children with COVID-19. Cell 2020; 183: 968-981.e7. [PubMed][CrossRef]

4. Morris SB, Schwartz NG, Patel P et al. Case Series of Multisystem Inflammatory Syndrome in Adults Associated with SARS-CoV-2 Infection - United Kingdom and United States, March-August 2020. MMWR Morb Mortal Wkly Rep 2020; 69: 1450-6. [PubMed][CrossRef] 
5. Størdal K, Ruiz PL-D, Greve-Isdahl M et al. Risk factors for SARS-CoV-2 infection and hospitalisation in children and adolescents in Norway: A nationwide population-based study. Preprint 5.7.2021. https://www.medrxiv.org/content/10.1101/2021.07.01.21259887v1 Lest 19.9.2021.

6. Radtke T, Ulyte A, Puhan MA et al. Long-term Symptoms After SARS-CoV-2 Infection in Children and Adolescents. JAMA 2021;326: 869-71. [PubMed][CrossRef]

7. Molteni E, Sudre CH, Canas LS et al. Illness duration and symptom profile in symptomatic UK school-aged children tested for SARS-CoV-2. Lancet Child Adolesc Health 2021; 5: 708-18. [PubMed] [CrossRef]

8. Zimmermann P, Pittet LF, Curtis N. How Common Is Long COVID in Children and Adolescents? J Pediatr Infect Dis 2021; 40. doi: 10.1097/INF.0oooooooooo03328. [CrossRef]

9. Frenck RW, Klein NP, Kitchin N et al. Safety, Immunogenicity, and Efficacy of the BNT162b2 Covid-19 Vaccine in Adolescents. N Engl J Med 2021; 385: 239-50. [PubMed][CrossRef]

10. CDC. COVID-19 Vaccine Task Force. Myopericarditis following COVID-19 vaccination. https://www.cdc.gov/vaccines/acip/meetings/downloads/slides-2021-08-30/03-COVID-Su-508.pdf Lest 15.92021.

Publisert: 7. oktober 2021. Tidsskr Nor Legeforen. DOI: 10.4045/tidsskr.21.0656

Mottatt 15.9.2021, godkjent 20.9.2021.

(C) Tidsskrift for Den norske legeforening 2023. Lastet ned fra tidsskriftet.no 26. april 2023. 